\title{
ENSILAGE DE MAÏS ET COMPOSITION DES REPAS pour Les PORCS a l'engrais
}

\author{
M. CHAMBOLle, C. FÉVRIER, J. RETTAGLIATI, et M. OUdiN \\ Station de Recherches sur l'Élevage des Porcs, \\ Centre national de Recherches zootechniques, I. N. R. A., \\ 78350 Jouy en Josas
}

\section{RÉSUMÉ}

\section{Expérience 1}

Deux régimes comprenant $80 \mathrm{p}$. Ioo de la matière sèche provenant du maïs sont distribués à des porcs mâles castrés et femelles entre 25 et $100 \mathrm{~kg}$ de poids vif. Le maïs est présenté soit, sous forme de grains ensilé (GE) soit, sous forme d'épi sans spathes (ESS). Il est supplémenté par un mélange de tourteau de soja, de farine de poisson et de complément minéral et vitaminique. Les animaux sont nourris suivant un plan de rationnement tel que l'apport de matière sèche avec ESS soit de Io p. Ioo plus élevé qu'avec GE

Les vitesses de croissance sont semblables, mais l'indice de consommation ( $\mathrm{kg}$ MS/kg gain) est supérieur avec ESS : $+0,29$ entre 35 et $70 \mathrm{~kg}(\mathrm{NS}) ;+0,43$ entre 70 et roo $\mathrm{kg}(\mathrm{P}<0,05)$ et $+0,34$ entre 35 et $100 \mathrm{~kg}(\mathrm{P}<0,10)$. Les refus sont moindres avec ESS et chez les mâles que chez les femelles.

Le rendement en carcasse est réduit de $\mathrm{r}, 25$ p. Ioo $(\mathrm{P}<0,05)$ avec ESS ; les femelles sont plus maigres que les mâles.

\section{Expérience 2}

On compare des régimes à base de maïs grain ensilé (GE) ou conservé par l'acide propionique (GP) pour lesquels le maïs constitue $80 \mathrm{p}$. 100 de la matière sèche, et distribué suivant le même plan de rationnement. Ces régimes sont distribués chaque jour soit, en deux repas identiques (M), soit, en un repas de maïs le matin et un repas de complémentation le soir (D).

Entre 35 et $99 \mathrm{~kg}$ on n'observe aucune différence sur la vitesse de croissance et l'indice de consommation.

Les refus sont moindres avec le maïs (GP) $(\mathrm{p}<0,05)$. Avec les repas $\mathrm{D}$, les carcasses ont tendance à être un peu plus maigres qu'avec les repas $M$ (réduction significative de pourcentage de bardière).

\section{SUMMARY \\ HIGH MOISTURE MAIZE AND COMPOSITION OF FATTENING PIG DIETS \\ Experiment 1}

Two diets containing $80 \mathrm{p}$. 100 maize dry matter were given to castrated male pigs and entire females between 35 and roo kg live weight. The maize was offered either as ensiled grains (EG) or as cobs without husks ( $\mathrm{CWH})$. It was supplemented by a mixture of soybean oil-meal, fish 
meal, mineral substances and vitamins. The animals were fed according to such a feeding schedule that the supply of dry matter with $\mathrm{CWH}$ was Io $\mathrm{p}$. Ioo higher than with $\mathrm{EG}$.

The growth rates were similar, but the feed conversion ratio ( $\mathrm{kg} D \mathrm{DM} / \mathrm{kg}$ gain) was higher with $\mathrm{CWH}:+0.29$ between 35 and $70 \mathrm{~kg}(\mathrm{NS}) ;+0.43$ between 70 and $100 \mathrm{~kg}(\mathrm{P}<0.05)$ and +0.34 between 35 and $100 \mathrm{~kg}(\mathrm{P}<0.10)$. Refusals were smaller with $\mathrm{CWH}$ and with males than with females.

Dressing percentage was reduced by 1.25 P. I00 $(\mathrm{P}<0.05)$ with $\mathrm{CWH}$; the females were leaner than the males.

\title{
Experiment 2
}

Diets containing 80 p. Ioo maize dry matter either in the form of ensiled maize grains (EG) or propionic acid treated maize grains (PG) and offered according to the same feeding schedule, were compared. These diets were given every day, either in two identical meals (M) a maize meal in the morning and a complementation meal in the evening (D).

Between 35 and $99 \mathrm{~kg}$ no difference was observed as regards growth rate and feed conversion ratio.

The refusals were smaller with the $\mathrm{PG}$ maize $(\mathrm{P}<0.05)$. There was a tendency for a little leaner carcasses with the $D$ meals than with the $M$ meals (significant reduction of the backfat percentage).

\section{MOUTUIRE DE MAÏS - GRAIN SEC PERFORMANCES DE PORCS CHARCUTIERS ET ALTÉRATIONS STOMACALES}

\author{
J. MOAL et J. CASTAING \\ Association générale des Producteurs de Mais, \\ 64000 Pau
}

\section{RÉSUMÉ}

Six moutures différentes et de granulométrie croissante d'un mélange contenant $74 \mathrm{p}$. Ioo de mais, 23 p. Ioo de tourteau de soja " 50 ", 3 p. Ioo de CMV (matières azotées brutes : I 8 p. Ioo $\mathrm{kcal}$ digestibles $/ \mathrm{kg}: 3350$ ) ont été distribués à des porcs charcutiers de 25 à Io3 $\mathrm{kg}$ de poids vif logés sur sol nu.

L'alimentation humide a été distribuée en deux repas journaliers. Les animaux ont été rationnés à raison de $2,4 \mathrm{~kg} /$ porc/jour après une période d'alimentation semi ad libitum.

Sur l'ensemble croissance-finition, le gain moyen quotidien et les indices de consommation sont d'autant plus défavorables que la mouture est plus grossière. De même le nombre de lésions de la zone gastro-øsophagienne diminue faiblement. 